\title{
A paz de Cristo seja contigo! Uma reflexão sobre violência e liturgia no Brasil
}

\author{
May the peace of Christ be with you! A reflection \\ on violence and liturgy in Brazil
}

\section{Júlio Cézar Adam*}

Escola Superior de Teologia (Faculdades EST), São Leopoldo, RS, Brasil

\section{Resumo}

A Teologia Prática é a reflexão da práxis teológica, a partir da práxis e para a práxis, o que a coloca frente ao desafio de apontar pistas de como lidar com a violência e não apenas incluíla no discurso teológico. Pretende-se neste artigo, portanto, refletir sobre a relação entre violência e liturgia, apontando tais pistas possíveis, no contexto brasileiro. 0 culto cristão como ação simbólica-representativa do Evangelho (Schleiermacher), nas diferentes tradições confessionais, reúne pessoas que experimentam as mais diferentes formas de violência. Mesmo assim, o culto corre o risco de celebrar ao largo da violência cotidiana, ou de camuflá-la ou ainda de reforçá-la. Quais são as possibilidades de enfrentamento e alternativa à violência na e a partir da liturgia, é algo que se procura tratar aqui. A metodologia utilizada é a de revisão bibliográfica, através da qual se busca, por um lado, apresentar

JCA: Doutor em Teologia, e-mail: julio3@est.edu.br 
aspectos do contexto da violência e, por outro lado, se busca analisar a função da liturgia e do culto cristão frente à violência. Na primeira parte do artigo, trata-se os complexos meandros da violência, principalmente a violência no contexto brasileiro. Na segunda parte, reflete-se sobre a relação entre violência e liturgia, principalmente analisando a teoria de Ernst Lange, sobre a função do culto de propiciar identidade, distância, celebração e festa, para, por fim, apresentar as possibilidades concretas da liturgia como alternativa à violência, analisando alguns dos elementos e formas que constituem a liturgia cristã. Ao longo do artigo, alguns filmes brasileiros são referidos como ilustração, descrevendo brevemente aspectos da narrativa dos filmes e traçando paralelos com o contexto.

Palavras-chave: Teologia Prática. Culto cristão. Liturgia. Violência.

\section{Abstract}

Practical Theology is the reflection of the theological praxis, starting from praxis and to the praxis, which puts it in front of the challenge of pointing out clues on how to deal with violence and not only to include it in theological discourse. This article intends to reflect on the relationship between violence and liturgy, pointing out possible clues in the Brazilian context. Christian worship as a symbolic action-representative of the Gospel (Schleiermacher), in the different confessional traditions, brings together people who experience the most different forms of violence. Even so, the cult runs the risk of celebrating the violence of the day or of camouflaging it or reinforcing it. What are the possibilities of confrontation and alternative to violence in and from the liturgy, is something that is thinking here. The methodology used is that of a bibliographical review, which seeks, on the one hand, to present aspects of the context of violence and, on the other hand, seeks to analyze the role of liturgy and Christian worship in the face of violence. The first part of the article deals with the complex meanders of violence, especially the violence in the Brazilian context. In the second part, we reflect on the relation between violence and liturgy, mainly analyzing the theory of Ernst Lange on the function of the worship of propitiating identity, distance, celebration and feast, to finally present the concrete possibilities of the liturgy as alternative to violence, analyzing some of the elements and forms that constitute the Christian liturgy. Throughout the article, some Brazilian films are referred to as illustration, describing briefly aspects of the narrative of the films and drawing parallels with the context.

Keywords: Practical Theology. Christian worship. Liturgy. Violence. 


\section{Introdução}

Culto e violência fazem parte do dia a dia do Brasil. A pergunta pela relação entre ambos, porém, não é algo tão comum. O dossiê de Pistis \& Praxis "As fronteiras das violências e o papel inclusivo da Teologia Prática" é uma escolha não só inovadora, mas também necessária. Não há dúvidas de que vivemos um contexto de muita violência. A Teologia Prática quer ser exatamente a reflexão da práxis teológica, a partir da práxis e para a práxis (HOCH, 2011, p. 61), o que a coloca frente ao desafio de apontar pistas de como tratar a violência e não apenas inclui-la no discurso teológico. Pretende-se neste artigo, portanto, refletir sobre a relação entre violência e liturgia, apontando tais pistas possíveis.

O culto cristão é uma forma muito clara de teologia na prática (MARASCHIN, 2011 p. 42). É algo que acontece, seguindo diferentes tradições confessionais, em todos os recantos do contexto brasileiro, reunindo pessoas que experimentam as mais diferentes formas de violência. Mesmo assim, o culto corre o risco de celebrar ao largo da violência cotidiana, ou de camuflá-la, ocultá-la ou ainda de reforçar a própria violência. Mesmo assim, há claras possibilidades de enfrentamento e alternativa à violência a partir da liturgia. Talvez esta seja exatamente uma das primordiais funções da liturgia cristã, como ação simbólicarepresentativa do Evangelho de Jesus Cristo: ser espaço de ação simbólica contra todo o tipo de violência.

Para tanto, desenvolve-se o artigo da seguinte forma: na primeira parte nos embrearemos pelos complexos meandros da violência humana, buscando entendê-la tanto em sua conceituação como na sua prática. Em um segundo momento, refletiremos sobre a relação entre violência e liturgia, para, por fim, apresentar as possibilidades concretas da liturgia como alternativa à violência, analisando alguns dos elementos e formas que constituem a liturgia cristã, como a confissão de pecados, o gesto da paz, o Kyrie eleison, as leituras bíblicas e a pregação, a eucaristia, os cantos e a música, entre outros. 


\section{A violência nossa de cada dia}

Segundo Morais (1985, p. 25) a violência está em tudo que é capaz de imprimir sofrimento e destruição ao corpo do ser humano, degradar ou causar transtornos à sua integridade e dignidade física, psicológica e mental. São, portanto, muitas as maneiras que a violência se apresenta em nosso cotidiano, sejam as formas mais visíveis, geralmente veiculadas pela grande mídia, como as guerras, a fome e o terrorismo; os assaltos, sequestros e assassinatos; a violência no trânsito; as formas mais invisíveis e disfarçadas, como a violência doméstica, o estupro, o abuso sexual, maus tratos a crianças e idosos, o bullying na escola, inclusive o cyberbullying, linchamentos, tráfico humano e de órgãos, genocídios contra indígenas e quilombolas; ou ainda a violência relacionada aos abusos e carências das instituições como os sistemas penitenciários e em outras instituições de reclusão e abrigo, o acesso caótico ao sistema de saúde, a precariedade e desumanidade do sistema habitacional; a exploração da terra e dos recursos naturais; ou ainda a violência sutil emocional e psicológica a que as pessoas estão diariamente submetidas, através das mídias, suas notícias, produções e seus apelos comerciais.

Percebe-se, assim, que a violência está presente em todos os espaços das relações humanas, causando danos físicos, morais e psicológicos a todo e qualquer ser humano, em todos os contextos, o que leva a questionar em que medida a violência é algo inerente à própria vida e, em que medida podemos encontrar estratégicas para superá-la, ou, no mínimo, de minimizá-la. O certo é que, enquanto lemos este artigo, em casa, no trânsito ou na rua, toda pessoa está diariamente exposta a algum tipo de violência. De onde surge afinal a violência e como ela se manifesta no dia a dia e porque em determinados contextos, como no Brasil, sua incidência é maior, são perguntas que surgem na reflexão.

Pode-se dizer, num primeiro momento, que o ser humano é por natureza violento. Teologicamente falando, o próprio pecado corrompe a relação pacífica do ser humano com Deus, e consequentemente consigo mesmo e com o próximo. Basta lembrar que após a queda, o castigo e a expulsão do paraíso (Gn 3, 14-24) - em si algo violento temos o relato de Caim e Abel, o primeiro homicídio narrado na Bíblia 
(Gn 4, 1-16). Sociologicamente também se trata a violência como algo típico do ser humano, presente ao longo de toda a nossa trajetória, se originando de necessidades e interesses antagônicos geradores de disputas por sobrevivência, domínio, controle ou, simplesmente, status e poder (MORAIS, 1985, p. 79). Esta visão do mal e da violência como algo intrínseco à natureza humana pode levar a certa naturalização da violência, como adverte Guimarães, para quem a violência é muito mais uma construção racional e cultural a ser refreada por meio de um esforço e uma ação, assim como também a paz deve ser pensada e construída (2004, p. 9).

Independente se a violência é resultado de algo nato ou de uma construção cultural, há contextos e períodos em que seres humanos são mais violentos que em outros, como em tempos de guerra, ou em espaços onde convivem facções e grupos com divergências ideológicas ou em luta por poder e controle de algo. Isto nos leva a buscar as raízes da intensificação da violência nas condições psicológicas, sociais, políticas, culturais e econômicas em que os grupos se encontram. Tomando como exemplo a violência no Brasil, vemos muito claramente que essa não só impregna todas as relações que vão sendo estabelecidas desde a chegada dos primeiros ibero-americanos, seja entre as pessoas e grupos, seja na relação com o próprio ambiente e seus recursos, como também ela se acentua em contextos onde as condições de relação e preservação da vida estão em risco, como nos aglomerados humanos das nossas grandes cidades, nas últimas décadas.

Olhando a violência brasileira mais de perto, percebemos que toda a formação do Brasil se dá através da violência. A conquista não só foi um embate violento entre culturas e a escravidão (PAULY, 2008, p. 1024), mas também uma forma de encobrimento — não descobrimento — da cultura do outro. Esta desigualdade e luta por poder irá marcar profundamente a sociedade, como algo endêmico, acentuando sobremaneira a violência, como Pauly (2008, p. 1025) irá bem caracterizar:

Os laços escravocratas do colonizador da Coroa, a sanha predatória das classes dominantes no Brasil independente e seu elitismo racista no Brasil republicano impediram que a nação pactuasse um contrato social razoável, 
no qual prevalecesse o 'reconhecimento do outro como sujeito de direito', estabelecendo-se uma sociedade na qual muitos se encontram à mercê de poucos, em que vige, sem interditos, acentuada assimetria no acesso a recursos, bem como sua distribuição, e a vida de muitos não tem o mesmo valor e significado da vida de alguns, somente pode ser instituída a 'guerra de todos contra todos' como modo de funcionamento regular e normal.

A violência seria, portanto, neste caso, resultado de um conflito originado na desigualdade de acessos a recursos e garantia de direitos. Ou seja, esta violência é gerada pela imensa desigualdade de direitos e oportunidades que até hoje ainda se perpetuam. $\mathrm{O}$ mesmo princípio de privilegiar uns através da exploração dos outros, descrito acima, caracteriza profundamente a maneira como concebemos a sociedade brasileira. Com isso, pode-se dizer que não são as populações pobres as mais violentas ou as que provocam a violência, como a grande mídia e as elites econômicas costumam acusar, mas sim, toda uma situação de injustiça e desigualdade social, por si só extremamente violenta, que está na base da estrutura social brasileira e da própria violência. Obviamente que quanto mais as pessoas estiverem expostas a esta desigualdade instaurada na sociedade, maior será a incidência da violência, algo muito transparente nas grandes cidades brasileiras.

Segundo Morais, o que leva o ser humano a reagir com violência é a ansiedade e o medo resultantes do sentimento de impotência, de fragilidade. Quanto mais impotente uma pessoa se vê de realizar seus sonhos, aspirações, desejos para si e para os seus, tanto maior será a brutalidade da sua violência (MORAIS, 1985, p. 33). Segundo o autor, a brutalidade é a violência dos fracos. Quanto mais concentradas e desprovidas de se realizarem como seres humanos estão, mais tensão será gerada. Por isso, nas cidades, a incidência maior de violência.

A falta de perspectiva e esperança, está muito bem retratada no filme Linha de passe (SALLES; THOMAS, 2008). A linha de passe no futebol é o momento e local certo onde um jogador precisa passar a bola ao outro, possibilitando, assim, o cumprimento da meta, o gol. Exatamente sobre isto trata o filme que leva este nome: a linha de passe na vida de pessoas na periferia do mundo, na megalópole São Paulo, na busca pela sobrevivência e por sentido. O filme é caracterizado por um realismo que, 
por vezes, dá a impressão de se tratar de um filme reportagem. Ele conta a história de quatro irmãos e uma mãe, que vivem na Cidade Líder, periferia da metrópole São Paulo. Em Linha de passe vemos de forma muito crua a marginalidade e a invisibilidade social, a falta de perspectiva, a falta de esperança e a impossibilidade humana de vir a ter — vir a ser — uma vida digna em uma cidade e em uma sociedade que invisibiliza a maioria dos seus cidadãos (ADAM, 2017). Como bem aponta Morais (1985, p. 44):

Quem já passou por estações de subúrbio pelo fim da madrugada, quem já observou pontos de ônibus quando o dia ainda nem se anunciava, viu nesses lugares quase lúgubres uma multidão de rostos sofridos esperando sua promíscua condução para mais um dia de produção que não lhes dará direito a adquirir o que eles mesmos produzem.

Como apontado acima, a incidência da violência em contextos de vulnerabilidade social não significa que as pessoas sejam mais violentas, mas sim que o grau de impotência que lhes foi imposto é tamanho, que atos de violência se apresentam como alternativa de liberação e sobrevivência, na maioria das vezes contra eles mesmos (MORAIS, 1985, p. 33). Uma das consequências disso, visível principalmente nas cidades de grande e médio porte brasileiras, é o medo permanente da violência, o que, em si, é uma grande contradição, uma vez que "a cidade que nasceu da tentativa humana de produzir um espaço solidário, tornou-se, ela mesma, uma mercadoria, perdendo assim sua finalidade primordial e tendo como única razão de se realizar, aumentar e favorecer o lucro" (MORAIS, 1985, p. 38).

A antropóloga Alba Zaluar também questiona a relação direta e causal entre pobreza e criminalidade. Segundo a autora, a violência no Brasil é algo complexo, alastrado em toda a sociedade, sendo as pessoas pobres as mais expostas. A violência é resultado de todo um sistema corrupto, injusto e violento. Para Zaluar, a violência já está muito antes da própria pobreza, em si, na formulação de leis penais; na facilidade com os poderosos conseguem ocultar seus crimes; nos vieses políticos que contaminam as estatísticas oficiais; na corrupção nas empresas, ONGs, na polícia e na política; na criação de bolsões de miséria, em lugares impróprios e precários; na ineficácia do policiamento e da investigação ou outra proteção institucional nas periferias; na falta de acesso a um sistema 
de educação profissionalizante adequado; no envolvimento forçado de jovens nas tramas do tráfico de drogas, nas milícias e contrabando das armas e do crime organizado, etc (ZALUAR, 2017, p. 36). A mídia, porém, acaba reforçando a ideia de que a violência esteja associada à pobreza e à reação — violenta — da população é, no sentido de punir e segregar ainda mais aqueles que vivem em situação de miséria, na lógica do "bandido bom é bandido morto" (VON SINNER e WESTPHAL, 2017), como única alternativa à resolução da violência.

De maneira muito explícita, quase como um espelho da desastrosa e conflitosa estrutura social que a sociedade brasileira engendrou para si, filmes escancaram a estrutura social, retratando-a como uma verdadeira máquina de produção ininterrupta de violência. São muitos os filmes que refletem esta realidade. Como exemplo, aqui, podemos referenciar o filme Cidade de Deus (MEIRELES, 2002), que retrata a vida e o destino de mais um aglomerado humano na cidade do Rio de Janeiro, a comunidade Cidade de Deus, nos anos 1980, onde os jovens, sem maiores perspectivas de profissionalização promissora, são impelidos para o universo das drogas, do crime organizado, o contrabando de armas, sem nenhuma intervenção eficiente do estado e suas instituições. De algumas dezenas de personagens jovens, todos condenados a destinos trágicos, apenas um, o Buscapé, encontra um caminho, quase ao acaso, no jornalismo fotográfico.

Cidade de Deus, corrobora os números estatísticos do país. Segundo dados da pesquisa do Mapa da Violência 2016, o número de pessoas mortas, apenas por armas de fogo no Brasil, de 1980 a 2014, são alarmantes:

Os registros do SIM (Sistema de Informações sobre Mortalidade) permitem verificar que, entre 1980 e 2014, morreram perto de 1 milhão de pessoas (967.851), vítimas de disparo de algum tipo de arma de fogo. Nesse período, as vítimas passam de 8.710, no ano de 1980, para 44.861, em 2014, o que representa um crescimento de 415,1\% (Mapa da Violência, 2016).

Agrava-se, ainda, o fato de que a sociedade além de gerar a violência, é totalmente ineficiente na forma de contê-la, com uma polícia mal paga, por vezes, envolvendo-se no crime, carecente de pessoal, situação que gera um índice elevado de impunidade, agravado pela 
morosidade do sistema judiciário, o total fracasso do sistema prisional, o que gera sistemas paralelos de justiceiros e os casos de linchamentos (VON SINNER; WESTPHAL, 2017). O resultado de toda esta violência é o quadro que temos hoje, no Brasil, onde sair na rua é quase como uma "roleta russa", onde qualquer um, a qualquer momento e em qualquer lugar, pode ser a próxima vítima de um assalto, sequestro ou assassinato, gerando talvez o único sentimento comum a todos os brasileiros, o medo. "Onde há medo, há ameaças; e onde estão as ameaças, está a violência" (MORAIS, 1985, p. 16). Por isso, cada vez mais as casas são cercadas com cercas elétricas, com sistemas de alarmes e câmeras ligadas a lucrativas agências de segurança, os carros são blindados, quando não se financia guarda-costas ou guarda permanentes para proteção, políticos querem revogar o estatuto do desarmamento. O medo adoece as pessoas (MORAIS, 1985, p. 14). Com medo, apenas reagimos, muitas vezes, com mais violência e não conseguimos nos articular para enfrentar as condições que geram e replicam a própria violência.

Segundo Zaluar, assim como a violência no Brasil é complexa e multidimensional, da mesma forma será o seu enfrentamento. Segundo a autora,

Devido ao seu caráter multidimensional [...] a criminalidade e a violência precisam ser pensadas e combatidas em várias frentes por outras instituições, assim como outros órgãos públicos, tais como hospitais e escolas, articuladas às associações que pertencem aos terceiro e quarto setores: associações recreativas, associações de moradores, alcoólicos anônimos e narcóticos anônimos, fundamentais na implementação de qualquer política de prevenção e tratamento (ZALUAR, 2017, p. 41).

Parece ser justamente aqui, nesta confluência de macropolíticas, de instituições e de espaços, de grupos e de iniciativas próximos ao cotidiano das pessoas, que o culto cristão pode dar também a sua contribuição, no sentido de apresentar um espaço público para reflexão, ação, mas acima de tudo, construção de sentido para a vida e de esperança. 


\section{A relação entre liturgia e violência}

Neste segundo ponto, pretende-se refletir sobre a relação existente entre a liturgia e a violência, por um lado, bem como apresentar aspectos referentes a função do culto cristão frente à violência.

\section{Definindo culto cristão frente à questão da violência}

O culto cristão é ação representativa (darstellendes Handeln), (SCHLEIERMACHER, 1850, p. 70) de todo o Evangelho. No culto circula o Evangelho em forma de ação representativa-simbólica, como comunicação pública da experiência cristã (ADAM, 2012, 251). Ou seja, o culto cristão recapitula, atualiza e divulga toda a história de Deus com seu povo, história registrada na Bíblia e na própria tradição do povo de Deus, a Igreja (VON ALLMEN, 2006, p. 21). Sendo recapitulação da história da salvação, atualização do Evangelho, todo culto é em si, um claro protesto contra todo e qualquer tipo de violência. Nem por isso, a liturgia e o próprio culto estão imunes à violência. $\mathrm{O}$ próprio culto nasce de um evento violento, o sacrifício de Cristo na cruz. Este ato violento está presente de forma implícita e explícita nos sacramentos. Todo o culto nada mais é que atualização e rememoração do sacrifício de Cristo na cruz, o confronto permanente com o pecado e a morte, condições humanas inalienáveis, mas também a exposição da violência humana e dos sistemas injustos que condenaram Jesus de Nazaré.

$\mathrm{Na}$ eucaristia rememoramos o sacrifício vicário de Cristo, corpo que se reparte e sangue que é derramado, para que o ser humano possa, reconciliado com Deus, tornar-se um novo corpo, o Corpo de Cristo. Através deste sacrifício, lembramos toda a desigualdade humana, a fome, as mesas divididas e inacessíveis ainda hoje, inclusive entre as tradições cristãs. De forma semelhante, no sacramento do batismo o ser humano é mergulhado na morte de Cristo, morrendo ao pecado, para poder ressuscitar com Cristo. Toda a vida da pessoa cristã outra coisa não é que um permanente e diário morrer a velha natureza humana, cumprindo-se apenas na morte derradeira no final e uma luta diária por testemunhar o Evangelho em um mundo marcado pelo mal, pela intolerância, o preconceito e a divisão. 
Mas não apenas nos sacramentos ${ }^{1}$ temos o aspecto da violência. Os ofícios casuais, como a confissão de pecados (reconciliação cristã), a bênção matrimonial, a confirmação, o funeral, enquanto rito de passagem, podem estar, muito mais, condicionando e determinando por papéis sociais e reforçando o status quo, que de fato carrega pastoralmente em amor as pessoas através de suas jornadas e passagens (WHITE, 1997, p. 204). O que é o rito da bênção matrimonial, senão um rito patriarcal de transferência da mulher das mãos de um pai, para um marido, diante de uma autoridade? Algo que James Alison muito bem aponta eu seu artigo sobre o culto em um mundo violento (ALISON, 2004, p. 133).

Sutilezas da própria liturgia vão revelar formas mais veladas de violência. A própria ordem litúrgica não deixa de ser uma imposição, como o próprio nome "ordo" sugere. O/a ministério/a ordenado/a (de ordem) como detentor/a de certo poder simbólico é restrito apenas a alguns que lograram enfrentar todo um processo de formação e avaliação. Em algumas instituições há condicionantes tradicionais como questões de gênero, que impedem mulheres e pessoas homoafetivas, não só da ordenação, mas também de determinadas ações e direções litúrgicas. Em especial nos cultos da tradição protestante, temos o privilégio da razão, em detrimento da expressão dos sentimentos, como a emoção ou mesma a relação mais próxima com a vida em sua singeleza e carência. Maraschin (2011, p. 35) denuncia que "as liturgias que realizamos são, quase sempre, logocêntricas. Circulam ao redor da palavra. [...] Às vezes ficamos na dúvida se o 'logos se fez carne' ou se, de fato, foi transformado num livro". Além disso, no contexto latino-americano, a liturgia foi, muitas vezes, utilizada com forma de legitimar um contexto de abuso de poder, como instrumento ideológico, geralmente usada contra os grupos em situação de vulnerabilidade, como os negros, os índios, as mulheres, homossexuais, as crianças, as pessoas portadores de alguma deficiência, pessoas de classes econômicas inferiores, outras expressões religiosas ou ideológicas, ou ainda pessoas que se opuseram a determinada imposição

1 Considera-se neste artigo os dois sacramentos Batismo e Eucaristia e Ofícios Casuais a Confirmação, Reconciliação Cristã, a Bênção Matrimonial, a Liturgia junto às pessoas enfermas, o Funeral Cristão e a Ordenação.

Rev. Pistis Prax., Teol. Pastor., Curitiba, v. 10, n. 1, 10-35, jan./abr. 2018 
hegemônica através da religião e do culto, como muito bem aponta Vannucchi (1982. p. 9 e p. 77):

[...] não se pode negar a evidência histórica de um culto tantas vezes ideologizado como parte integrante ou homologante do status quo nacional, desviando assim os crentes dos caminhos concretos de sua libertação, suprimindo a liberdade dos filhos de Deus, em lugar de a expressar.

[...] A muitos parece que o universo litúrgico limita, aliena, isola e paralisa e que, por isso mesmo, a Igreja através do agenciamento de ritos, manteve, durante séculos, gerações seguidas sob seu controle, fazendo das populações sofredoras os 'fregueses' dóceis de seus sacramentos e de suas promessas de uma vida posterior, eternamente feliz.

Também aqui, a filmografia brasileira é rica em retratar estes conflitos sociais e o quanto eles estão influenciados e relacionados a conflitos religiosos e litúrgicos, como podemos ver no filme Deus e Diabo na Terra do Sol (ROCHA, 1964), onde o elemento religioso está presente de forma muito explícita tanto do lado dos despossuídos em forma de messianismo, quanto do lado do coronelismo, representado principalmente pela instituição religiosa hegemônica, no caso a Igreja Católica. Já o conflito entre diferentes confissões religiosas pode ser visto no filme $O$ Pagador de Promessas (DUARTE, 1962), cujo enredo gira em torno ao sincretismo religioso, como parte do catolicismo popular, e as religiões de matriz africana, e catolicismo institucional (ADAM, 2017). Portanto, ao relacionar a liturgia com a violência faz-se necessário um olhar crítico sobre a própria liturgia, seus usos e abusos. Feita essa importante ressalva, pretende-se a seguir e, através de uma teoria do culto cristão, refletir sobre a sua função teológica e social do culto frente às tantas situações de violência que fazem parte da vida das pessoas que o celebram.

\section{A função do culto cristão em um contexto de violência}

A função principal e central do culto cristão é despertar e alimentar a fé cristã, como aponta Heimbrock: "Culto cristão não tem, em primeiro ou último lugar, nenhuma pretensão específica, mas quer ser 'agir 
representador', quer dar expressão à alegria do ser humano pela libertação de Deus, expressão total, se possível" (1993, p. 9). Toda celebração litúrgica significa, portanto, um abrir-se e um deixar-se surpreender por algo maior que qualquer ação humana, independentemente de quão justa, digna e do nosso dever essa ação possa ser. Por isso, toda forma de objetivação para os próprios propósitos, por mais nobres e necessários que sejam, como a superação da violência, viola a essência do culto cristão. Isto, porém, não significa dizer que o culto seja celebrado num vácuo cultural e social. $\mathrm{O}$ culto só é possível pela sua dimensão humana, a qual se encontra sempre presente na essência da própria liturgia, como serviço encarnatório de Deus para dentro da realidade concreta.

A definição do teólogo luterano, Peter Brunner (1968), valendo-se do termo alemão Gottesdienst, corrobora a ideia apresentada acima. O termo Gottesdienst permite ao mesmo tempo dizer que o culto é serviço de Deus à comunidade e serviço da comunidade perante Deus. Nesta compreensão, culto é sempre uma reação àquilo que Deus fez e faz em Jesus Cristo, o culto pleno. O serviço da comunidade perante Deus é o serviço de amor ao próximo, por meio da fé, fé despertada e mantida por Deus. Nos dois movimentos é sempre Deus quem age (WHITE, 1997, p. 15). Neste sentido, todo o impacto social do culto na superação da violência, deve brotar da própria liturgia, do serviço que Deus presta ao seu povo, a Igreja.

Aplicando este princípio para a temática da violência, podemos dizer que não é o tema da violência que irá determinar a liturgia do culto e sua função, mas a partir da liturgia em si, como ação representativasimbólica do Evangelho de Jesus Cristo, se constrói, se expressam, se articulam liturgicamente formas de tratar o tema da violência, como tema pertinente à comunidade que se reúne em culto. Como de fato isto se dá, é algo a ser refletido. Tomemos aqui uma perspectiva. O culto sempre irá provocar algo nas pessoas, na comunidade e no mundo, algo que vai além da sua função primeira, como ação e serviço de Deus que cria e mantém a fé, o que Rössler (1976) chama de "efeitos colaterais". A partir destes efeitos colaterais do culto, Ernst Lange (1987) defende a existência de quatro funções que o culto causa na pessoa e na comunidade que o celebra: identidade, distância, festa e celebração. 
O culto cria identidade nas pessoas que o celebram, funcionando como um espelho, através do qual a comunidade se vê e se reconhece. Esta identidade não é uma simples identidade cultural ou social, mas uma identidade que vem de fora, dada pelo próprio Deus, por meio de Jesus Cristo. É através de Cristo e por meio dele que a comunidade se reconhece.

Onde as pessoas procuram pela sua religião, ali elas procuram por identidade. Pois nós, pessoas, não nos fomos dadas, mas encarregadas de algo. [...] Religião organizada é, desde sempre, um instrumento cuja ajuda permite às pessoas formarem uma imagem de si próprias, certificar-se dela e entender-se em relação a ela. [...] A religião reivindica e experimenta identificar o ser humano de fora de si mesmo como o criado, como o que por Deus foi chamado e nomeado. Pois em Jesus encontramos [...] o ser humano assim como ele deve ser, com uma grande força convincente. [...] Deus é a origem dessa humanidade (LANGE, 1987, p. 85).

Na relação com a violência, a identidade dada a partir de Cristo permite que a comunidade reconheça sua humanidade e resista a todas as formas de violência. A violência é justamente a deturpação da identidade humana.

$\mathrm{O}$ culto cristão gira também em torno de distância. Mesmo que o culto esteja imbricado com a realidade e o contexto, ele é um momento consagrado, que cria um espaço de distanciamento, de avaliação do contexto e de si próprio, de contato com o alternativo, o utópico, o que Lange nomeia como um contramundo, como uma força de resistência, oposição e subversão da ordem.

Onde as pessoas procuram por sua religião, ali elas também procuram por distância. [...] Pessoas procuram por religião, porque precisam de distância, distância em relação a sua identidade desfigurada e libertação dela, ao menos por certo tempo, no interesse de novos começos. [...] Pois o anárquico em nós, o bem e o mal que reprimimos, é tão forte que necessita de válvulas para não acabar com toda a ordem. [...] (espaço para) a festa e a brincadeira. [...] O mundo da religião não é nenhum mundo obscuro ou supramundo, pelo menos não necessariamente, mas ele é contramundo, ao menos em parte. E, portanto, ele permite distância, crítica e autocrítica, superação do cotidiano, pelo menos no jogo litúrgico, no ato simbólico. Ele (sc. Jesus) nos identifica como irmãos do reino de Deus, que realmente é alternativo em relação ao mundo, no qual estamos presos e com deficiências, um contramundo, infinitamente mais sério que o mundo lúdico 
da religião organizada, só ligado a ele por morte e ressurreição e, não obstante, presente em Jesus, real e eficaz, antecipado no Espírito e na verdade da humanidade contagiante de Jesus. Esse contramundo não é somente espaço de liberdade, mas campo de força (LANGE, 1987, p. 86).

Diante da violência cotidiana e avassaladora, o culto cria, por meio da distância, um espaço para refletir sobre a própria violência e sobre as possibilidades de contraposição que o Evangelho aponta. O assunto do culto ainda gira em torno da celebração. O culto cria um espaço para celebrar a vida em sua humanidade, no seu significado mais autêntico e profundo.

Pessoas procuram por religião porque buscam possibilidades de celebrar a existência. E isso é vital. [...] Necessitamos da celebração para dissolver essa contradição, pelo menos para tentar dissolvê-la. [...] O próprio Jesus em pessoa é aquilo que tentamos com muito esforço em nossas celebrações. Ele é o acontecimento em que nossa humanidade fica inequívoca, em que seu verdadeiro significado vem à tona. O acontecimento Jesus é a festa do ser humano, e a liturgia, em seu sentido mais profundo, é a repetição memorial, é a reapresentação dessa festa (LANGE, 1987, p. 87).

A violência usurpa das pessoas a possibilidade de celebrar a vida. $\mathrm{O}$ culto como celebração festiva e alegre da boa notícia que é Jesus Cristo, possibilita este contrassenso à violência. A violência e a morte não resistem à celebração da vida. Por fim, o culto gira em torno da festa. O culto cristão é jogo lúdico, brincadeira, possibilidade de inverter subversivamente a realidade e sua crueza e crueldade.

Pessoas procuram por sua religião, porque se encontram em busca de possibilidades de jogo lúdico. Elas necessitam do jogo lúdico para a vida. Jogando, e só jogando, chegaremos às pegadas das possibilidades inesgotáveis de nossa existência. Jogando, descobrimos alternativas para o comportamento de costume, transcendemos os limites de nossos papéis cotidianos e experimentamos outros, testamos soluções de problemas, contrárias às de praxe. O jogo lúdico é o campo de provas da nossa liberdade. Brincando, uma criança descobre e conquista seu corpo e seu mundo. No jogo do amor sexual é testada a situação em que o amor ocorre de fato. Mesmo a condição de nossa atual sobrevivência, o planejamento 
para o amanhã é jogo, é o ensaio de soluções alternativas para o problema. [...] Liturgia como jogo lúdico [...] Para a criança que se levanta e ensaia os primeiros passos, como se pudesse andar, sua brincadeira, longe de carecer de seriedade, é algo profundamente sério e, além disso, também muito doloroso, já que cai sem parar. Mas não aprenderá a andar senão brincando dessa maneira. Todos nossos passos de aprendizado contêm esse elemento da antecipação, do jogo, do teste, do experimento. [...] nós jogamos junto e descobrimos, assim, que a vida também funciona de outro jeito. Por esse prisma, a Santa Ceia, a Eucaristia, é o maior jogo já descoberto. É o rito em que pessoas brincam de reino de Deus, antecipando aquilo que da consumação ainda se encontra radicalmente ausente, antecipando sua consumação e a consumação do mundo, e se comportando e fazendo por causa de Jesus como se não existissem todas as separações e deficiências que destroem nossa vida conjunta: nem judeu nem grego, nem escravo nem senhor, nem homem nem mulher (LANGE, 1987, p. 89).

Paradoxal e espantosamente, o contexto brasileiro que é tão marcado pela violência é também o contexto marcada pela festa, a dança, a música, o carnaval, a sensualidade, o riso e a folia. O culto deveria absorver muito mais o caráter da festa, onde podemos brincar de Reino de Deus e burlar todas as formas explícitas e sorrateiras de violência.

\section{A liturgia como forma de superação da violência}

A partir dessa reflexão sobre a função do culto cristão frente à realidade de violência, analisemos alguns dos elementos e formas litúrgicas, averiguando seu potencial de contraposição prática à violência. Antes, porém, de passar a esta análise mais detalhada, é importante fazer duas observações: primeira, independente da estrutura litúrgica do culto, o simples fato de nele se reunirem pessoas para refletir e celebrar como ação representativa-simbólica o Evangelho, já representa um potencial social de transformação. Quais outros espaços reúnem hoje tantas pessoas, por uma hora ou mais, semanalmente, para ouvir, refletir e se expressar, em conjunto? O segundo aspecto a ser ressaltado é o fato de que o culto sozinho, durante uma hora de duração, com todo seu potencial litúrgicosimbólico, sem uma relação maior com a abrangência do ministério 
cristão, de toda a ação da Igreja, a koinonia, a martiria, a educação cristã e o testemunho e a diaconia, e ainda uma ampla articulação social e política, não causa a transformação necessária dentro do quadro complexo de violência que temos aqui refletido (ADAM, 2012).

Confissão e remissão de pecados: O elemento da confissão e remissão de pecados é um elemento fundante da liturgia, uma vez que todo o Evangelho é uma grande obra de redenção. Este elemento está relacionado ao sacramento do batismo (KIRST, 2003, p. 38), rito através do qual a pessoa é agraciada com a possibilidade de uma nova relação com Deus e, consequentemente, entre irmãos e irmãs. Por causa de Jesus Cristo que morreu para redimir toda a criação do pecado, agora toda pessoa pode, através de um banho, iniciar uma nova relação com Deus.

A confissão de pecados surge na liturgia do culto primeiramente com um gesto de reconciliação comunitária. O elemento mais próximo deste antigo gesto de reconciliação é o que hoje temos como gesto da paz (elemento a ser trabalhado a seguir), localizado, em muitas tradições, antes da comunhão eucarística. Somente mais tarde, como uma ampliação da confissão individual feita ao sacerdote e como uma democratização da oração preparatória, no início do culto, a confissão torna-se um momento de confissão e reconhecimento do pecado humano diante de Deus.

Diante da violência, este elemento litúrgico é uma oportunidade clara para reconhecer a realidade do pecado que estamos todos envolvidos. O pecado, cujo pagamento é a morte, corrompe todas as relações. Toda tentativa humana de libertar-se do pecado, agrava ainda mais a condição de morte a que estamos submetidos. Somente em Deus, por meio de Jesus Cristo, temos acesso ao perdão e a possibilidade de, sempre de novo, recomeçar. Muito mais do que um rito penitencial, ou ainda de uma autopunição moral, o elemento da confissão nos confronta com a realidade de afastamento de Deus e morte que corrompe toda a criação, cuja violência é uma das tantas formas de manifestação. Confessar o pecado é assumir-se como parte da violência sistêmica e cotidiana e buscar em Deus força e orientação para efetivamente contrapor a violência.

Gesto da paz: este elemento, tradicionalmente, faz parte da Liturgia da Eucaristia. Através deste elemento litúrgico as pessoas saúdam-se entre si, através de um aperto de mão, um abraço, um beijo na face (ósculo 
santo), como gesto de reconciliação e expressão da paz comunitária. No Novo Testamento encontramos seguidamente a expressão "ósculo santo", provavelmente um beijo na face (Rm 16,16; 1Co 16,20; 2Co 13,12; 1Ts $5,26 ; 1 \mathrm{Pe} 5,14)$, o que mostra ser este um gesto da vida comunitária (KIRST, 2003, p. 70s.). No culto, já nos dois primeiros séculos, o gesto marcava a reconciliação comunitária, antes de participar da Eucaristia (Mt 5, 23-24 e Tg 5, 16).

Ao que tudo indica, ela (a reconciliação) era parte irrenunciável da Liturgia da Eucaristia. No rito da reconciliação, as pessoas cristãs reconheciam e confessavam a Deus e à comunidade os atos com os quais havia quebrado a unidade comunitária, buscando a reconciliação, reatando as relações entre irmãos e irmãs da comunidade. A reconciliação encontrava sua expressão litúrgica no gesto da paz. Ela não era uma ação individual, de pessoas isoladas, mas um ato litúrgico conjunto, de confissão e intercessão recíproca e comunitária (KIRST, 2003, p. 71).

Por isso, seu lugar adequado é antes da comunhão. Através dele, a comunidade expressa o desejo de viver em autêntica comunhão, reconciliada entre si e em paz com Deus. O gesto da paz não é um faz de conta, uma paz forçada, disfarçada e sínica. Ele expressa a esperança de que um dia a paz será uma realidade e a comunhão eucarística é seu prenúncio. $\mathrm{O}$ gesto da paz pode, portanto, ter lugar em outras partes do culto, como na Liturgia de Entrada, após o anúncio do perdão, como parte do preparo da mesa da Ceia. Para fora do culto, o gesto da paz pode proporcionar a vivência de um comprometimento com aquela pessoa que está próxima, fortalecendo, assim, os vínculos da comunidade, na busca pela vivência da paz de Cristo.

Kyrie eleison: a expressão em grego, significa Senhor, tem piedade de nós! Nos tempos antigos, o uso da exclamação Kyrie eleison era muito amplo. $\mathrm{Na}$ vida pública romana, ela era usada para saudar o imperador. Divindades de outras religiões eram veneradas com Kyrie eleison por seus fiéis. No Novo Testamento, Kyrie eleison era o clamor dos miseráveis ao seu Salvador (cf. Mt 15,22; 17,15; 20,30). Quando os cristãos passaram a incluir a exclamação Kyrie eleison no culto, estavam com isso confessando Jesus Cristo como único Salvador e ajudador em todas as necessidades, e negando a veneração 
divina a qualquer senhor deste mundo. O Kyrie entrou na liturgia ocidental ao redor do ano 500. Sua versão clássica era assim:
P.: Em paz oremos ao Senhor:
C.: Tem piedade, Senhor!
P.: Pela paz que vem do alto, e a salvação dos oprimidos, oremos ao Senhor:
C.: Tem piedade, Senhor!
P.: Pela paz do mundo inteiro, pela divulgação do Evangelho e o testemu- nho do povo de Deus, oremos ao Senhor:
C.: Tem piedade, Senhor!
P.: Por esta família de Deus e por todos os que aqui oferecem sua adoração
e louvor, oremos ao Senhor:
C.: Tem piedade, Senhor!
P.: Para sermos libertos de ódio, angústia e opressão, oremos ao Senhor:
C.: Tem piedade, Senhor!
P.: Por graça, socorre-nos, Senhor!
C.: Amém. (PAJARES ALONSO, 2010).

Como se percebe nessa versão clássica do Kyrie, suas súplicas clamam a Deus pela paz do mundo, pela salvação e libertação dos perseguidos e oprimidos, pela comunidade cristã e seu testemunho. Nas origens, coro e comunidade levantavam essa súplica, enquanto o bispo entrava na igreja, dirigindo-se ao altar para iniciar o culto. Ou seja, no início do culto, ao começar seu encontro com Deus, uma das primeiras coisas que a comunidade cristã faz é se lembrar do mundo ao seu redor e suplicar a Deus pelas dores deste mundo e pelo testemunho que ela, a comunidade, lhe deve. Portanto, com o seu culto, a comunidade cristã não se retira do mundo. Com seu culto, a comunidade cristã coloca-se dentro do mundo com suas dores. Kyrie eleison é, portanto, na origem, um clamor coletivo da comunidade pelas dores do mundo e não um clamor individual das pessoas pelo perdão dos seus pecados. Mais tarde, as súplicas foram eliminadas da Litania do Kyrie eleison, que, isoladas e fora de contexto, se transformaram em gritos de penitencia individualista, acabando por serem colocadas após a Confissão de Pecados.

Em uma realidade marcada pela violência, o Kyrie devolve à comunidade reunida a possibilidade de lamento e de clamor. Como um grito das profundezas da miséria humana dirigido a Deus, este elemento 
possibilita trazer a realidade de violência para dentro do culto e interceder pela misericórdia de Deus, na fé e na esperança de que Deus vê aflição e ouve o clamor do seu povo e desce para socorrê-lo (Ex 3,7).

Oração: No culto, ao lado da música e do louvor, a oração é a forma mais clara de resposta, de reação, de ação da comunidade diante de Deus e com Deus. A oração cria e desperta a fé. Cria intimidade com Deus, consigo mesmo e com o grupo que ora em conjunto, pois orar é despirse diante de Deus. Orar é permitir-se ser olhado por Deus na inteireza e na fragmentariedade humana. Agradecer e pedir, clamar, confessar e interceder é tirar de cima de si o que pesa e deixar que Deus seja Deus. Ao orar em um grupo, a sensação de medo desaparece, influindo no organismo dos envolvidos a nível biológico, psicofísico, emocional e espiritual (VON HOF, 2016, p. 52). O culto pode abrir espaço para a oração individual, em silêncio, sem deixar de privilegiar a oração comunitária. Estudos mostram que a oração restaura e cura, pois a oração desobstrui os poros da alma (EVANS, 2002, p. 122).

Retomando Ernst Lange (1987), oração tem a ver com a identidade e a distância, como vimos acima. Em uma sociedade violenta, orar auxilia as pessoas a expressar o medo, a insegurança, a angústia e a revolta. Juntamente com a oração, o elemento do silêncio é de grande importância, como preparação, reflexão, distanciamento. A possibilidade de silenciar no culto é de grande importância depurativa. Momentos de silêncio podem acontecer no início do culto, após leituras, como oração, bem como cultos especiais totalmente dedicados ao silêncio.

Leituras bíblicas e Prédica: Todo o culto é ação-representativa com base na tradição bíblica, de forma que o culto nada mais é do que a Palavra de Deus vertida em forma de rito e liturgia, ação simbólica. As Escrituras, como relato da relação de Deus com o seu povo, reproduzem a vida humana, com suas cruzes e suas glórias, seus tempos de guerra e violência e seus tempos de paz e dignidade. Escutar a Palavra de Deus, por meio das Escrituras, é uma forma de rememorar e atualizar como o povo enfrentou a vida ao longo da jornada e buscar orientação para viver hoje. Tão somente ouvir as leituras bíblicas, em um mundo sobrecarregado de muitas vozes sedutoras e conflitantes, é algo de grande relevância diante da violência. 
Da mesma forma, a pregação da Palavra é um momento de ouvir, mas também de refletir sobre a Palavra e buscar alternativas para a violência. A pregação é viva vox Evangelii (voz viva do Evangelho) para dentro do tempo presente e da vida das pessoas, voz criadora, transformadora e curativa. A pregação possibilita toda forma de denúncia profética à violência endêmica da sociedade, assim como anúncio da esperança pela superação de toda maldade (ADAM, 2013).

Eucaristia e Santa Ceia: A Ceia talvez seja a parte mais integradora e orientadora do culto, por isso, uma das mais restaurativas, por sua concretude e por sua força simbólica, em um contexto de violência, desagregação, desunião. Como sacramento, a graça de Deus é oferecida como contínua atividade de Deus no mundo, como possibilidade de nova vida, como reestabelecimento da antiga ordem e promessa esperançosa pela Grande Ceia do Reino (EVANS, 2002, p. 123). A Ceia tem a ver com alimentos, partilha, comunhão das pessoas entre si e com Deus. Ela é uma comunhão autêntica que rompe toda a lógica humana de sociedade (LANGE, 2012). É festa, brincar de Reino de Deus, como Ernst Lange diz. Todos esses aspectos faltam na atualidade. $\mathrm{Na}$ ceia, acontece uma integração por excelência, entre as pessoas (horizontal) e das pessoas com Deus (vertical). H.-Martin Barth (1984, p. 519) considera o comer e o comer em comunidade como algo de grande importância para o restabelecimento da saúde integral. Se o culto cristão é o resumo simbólico-representativo, a Santa Ceia é o espaço por excelência, o ápice dessa expressão, na qual participamos, de forma real e concreta. Nela nos tornamos, de fato, um só corpo, em Cristo. Pensando na relação com a violência, Evans aponta que:

A comunhão nos chama a lembrar a dádiva do perdão e da renovação através da morte de Cristo. Ela é tanto um memorial do sacrifício de Cristo como uma participação na vida eterna. Ao participar da comunhão, somos lembrados de que tudo o que comemos e bebemos tem uma qualidade sacramental, que o partir do pão é um sinal de hospitalidade. A comunidade do culto é lembrada de que somos como um corpo partido, derramando sangue. Somos partidos, estamos em enfermidade e sofrimento, precisamos de cura; no entanto, o sacramento nos mostra de forma tangível o sinal de Deus, a nutrição vinda de Deus, o dom da vida e da saúde 
concedido por Deus. Não importa quão quebrados estamos, Cristo nos renova (EVANS, 2002, p. 124).

Situados na parte final da oração eucarística, os dípticos ou mementos incluem na comunhão de Deus todos os que já partiram dessa vida, mas que não estão separados do amor de Deus. Para pessoas enlutadas que perderam seus entes queridos por causa da violência, este é, sem dúvida, o elemento de maior valor terapêutico e também de resistência social. Mesmo que a violência interrompa as relações, na Eucaristia celebramos a união eterna, a comunhão do Corpo de Cristo. Além disso, a comunhão com Cristo na ceia é uma antecipação da grande comunhão no reino prometido por Deus, mediante a ressurreição de Cristo, algo subversivo, pois anuncia o fim de toda a violência.

Música, hinos e cantos: a Bíblia está repleta de cânticos, pois toda a criação canta a Deus; conforme o livro de Jó $(38,7)$, na manhã da criação, as estrelas cantavam em coro. Os Salmos eram cantados em responsório, intercalando as leituras bíblicas. O líder de canto ou o coro cantava as estrofes e a comunidade respondia com uma antífona, um estribilho (KIRST, 2003, p. 30). Destaca-se a alegria do cântico de Maria logo após a anunciação do nascimento de Jesus (Lc 1, 46-55). Também para Jesus e sua comunidade de discípulos, o canto era importante, conforme nos relata o evangelho de Marcos, no relato da Santa Ceia: "e tendo cantado um hino, saíram para o Monte das Oliveiras" (Mc 14, 26). O apóstolo Paulo recomenda: "Falai uns aos outros com salmos e hinos e cânticos espirituais", assim recomenda Paulo aos efésios (Ef 5,19). Não admira que a maioria dos cantos litúrgicos (Glória, Aleluia, Sanctus, Agnus Dei, Fração, Bênção Aaronita, etc.) sejam textos bíblicos musicados.

Os cantos baseados em textos bíblicos são ótimos recursos para reforçar a mensagem bíblica e enfatizar o tema do culto. Podem ser cantados no início ou no final do culto ou após a interpretação. Os próprios textos bíblicos, assim como os Salmos, podem ser cantados. E mais ainda: A liturgia toda, como uma construção bíblica, poderia ser cantada. Os cânticos são "[...] como uma pausa na música ou os momentos de silêncio num discurso. Tem a função de deixar ecoar, deixar ressoar em nós a 
Leitura Bíblica, que acabou de acontecer, e de preparar-nos para a leitura seguinte" (KIRST, 2003, p. 30).

A música e o canto são, portanto, formas de louvor, de expressão de alegria, de tristeza, são espaços para a reflexão ativa sobre os temas bíblicos e teológicos. Famoso é o ditado brasileiro que diz que "quem canta, seus males espanta”. A música no culto é de grande importância na reflexão contra todas as formas de violência.

Bênção e Envio: a Bênção e o Envio são os principais elementos da Liturgia de Encerramento do Culto Cristão. Bênção não é uma oração nem um voto, mas uma combinação de ambos. É um rito de palavras e gestos que coloca em relação aquilo que abençoa, o abençoado e Deus. Paz, força, graça, perdão, consolo, luz estão concentrados na bênção.

A Bênção é pronunciada pela pessoa que conduz a liturgia, com os braços estendidos e as mãos voltadas para baixo, sobre a comunidade. Ela "é a declaração de favor divino, articulada por alguém de autoridade e dirigida a pessoas" (KIRST, 2003, p. 76). É mais que um desejo piedoso e menos que um ato sacramental. É um elemento que foi introduzido no culto por volta do séc. XII. Importante observar que votos e saudações similares acorrem em outros momentos do culto, como a Saudação apostólica, no início, a saudação e a bênção do púlpito (KIRST, 2003, p. 76).

O Envio é quase uma continuidade da Bênção. Recebemos a Bênção para sermos enviados ao mundo. Ou, porque somos enviados ao mundo, precisamos da Bênção de Deus. Algumas tradições tem o Envio antes da Bênção. No Envio, a pessoa oficiante impele a comunidade para sair e servir ao Senhor no mundo. A comunidade, por sua vez, em resposta, agradece a Deus por essa incumbência ${ }^{2}$. A forma clássica é: O. Ide em paz e servi ao Senhor! C. Demos graças a Deus.

O Envio nos lembra nossa tarefa como pessoas batizadas: ser luz do mundo. Por isso, a Bênção e o Envio poderiam ser pronunciados desde a fonte batismal, revolvendo suas águas e relembrando assim o compromisso batismal da pessoa cristã.

2 KIRST, 2003, p. 77. 


\section{Considerações finais}

Percebe-se, portanto, através destes elementos litúrgicos analisados, que há, sim, no culto cristão um potencial, não só para refletir sobre a violência e buscar deliberadamente alternativas a ela, mas também, por ser o culto ação simbólico-representativa do Evangelho, ele possibilita à comunidade que o celebra uma experiência alternativa de vida.

Vimos que o culto cristão é premissa para o encontro e oferece também a possibilidade para uma reflexão crítica sobre a realidade cotidiana. É perceptível ao analisarmos a relação entre culto e violência nas religiões, que a religião, que ao mesmo tempo em que a religião estabelece ações de natureza violenta, procura também, e de maneira simultânea, desenvolver e promover ações que oportunizem ao individuo um maior grau de dignidade, condição essencial para que o ser não se torne violento e saiba lidar com certo grau de violência inevitável à vista da condição da sociedade em que vive.

\section{Referências}

ADAM, J. C. Deus e o Diabo na Terra do Sol: Lived Religion, Conflict and Intolerance in Brazilian Films. In: GANZEVOORT, R. R.; SREMAC, S. (Ed.). Lived Religion and the Politics of (In)Tolerance. Cham: Palgrave, 2017. p. 111-132.

ADAM, J. C. Liturgia com os pés: estudo sobre a função social do culto cristão. São Leopoldo: Sinodal/EST, 2012.

ADAM, J. C. Mal-estar no púlpito: repensando teologicamente a pregação cristã na sociedade da informação. Estudos Teológicos, v. 53, p. 160-175, 2013.

ALISON, J. Worship in a Violent World. StudiaLiturgica, v. 34, n. 2, p. 133-146, 2004.

ALLMEN, J. J. von. O culto cristão: teologia e prática. 2 ed. São Paulo: ASTE, 2006.

BARTH, H.-M. Die therapeutische Funktion des Heiligen Abendmahls. Pastoraltheologie, n. 73, p. 512-525, 1984.

BRUNNER, P. Worship in the Name of Jesus. St. Louis: Concordia, 1968. 
ADAM, J. C.

CIDADE DE DEUS. Direçao: Fernando Meireles. Codireção: Katia Lund. Produção: Andrea Barata Ribeiro Maurício Andrade Ramos. Coprodução Marc Beauchamps. Produção executiva: Donald Ranvaud e Walter Salles. Roreiro: Vráulio Montovani. Baseadlo em Cidade de Deus de Paulo Lins. Narração. Alexandre Rodrigues. 02 Filmes. Globo Filmes, 2002. 1 DVD (130min), color.

DEUS E DIABO NA TERRA DO SOL. Direção: Guaber Rocha. Roteiro: Glauber Rocha. Wlater Lima Jr. Elenco: Geraldo Del Rey. Yoná Magalhães. Maurício do Valle. Othon Bastos. Gênero: Drama, 1964. 1 DVD (115 min), color.

EVANS, A. R. O ministério terapêutico da Igreja: programas praticos para Ministérios de Saúde. São Paulo: Loyola, 2002.

GUIMARÃES, M. R. Um novo mundo é possível. São Leopoldo: Sinodal, 2004.

HEIMBROCK, H.-G. Gottesdienst: Spielraum des Lebens. Sozial - und Kulturwissenschaftliche Analysen zum Ritual in praktisch-theologischem Interesse. Kampen/ Weinheim: Kok/ Deutscher Studien Verlag, 1993.

HOCH, L. C. Reflexões em torno do método da Teologia Prática. In: SCHNEIDERHARPRECHT, C; ZWETSCH, R (org.). Teologia prática: no contexto da América Latina. 3. ed. São Leopoldo: Sinodal/EST, 2011. p. 59-72.

KIRST, N. A liturgia toda: parte por parte. 2. ed., rev. atual. São Leopoldo: Sinodal, EST, 2003.

LANGE, E. Predigen als Beruf: Aufsätze zu Homiletik, Liturgie und Pfarramt. 2. Aufl. München: Kaiser, 1987.

LANGE, D. G. Sacramento da Santa Comunhão. Tear: Liturgia em Revista. São Leopoldo, n. 39, dezembro de 2012. p. 3-08.

LINHA DE PASSE. Direção: Walter Salles e Daniela Thomas. Roteiro: Bráulio Mantovani (colaborador). Walter Salles. Daniela Thomas.George Moura. Elenco: Vinícius de Oliveira. João Baldasserini. Geraldo Rodrigues. Kaique de Jesus José Trassi. Mateus Solano Sandra Corveloni.Gênero: Drama. 2008. 1 DVD (133 min), color.

WAISELFSZ, J. J. Mapa da violência. Homicídios por armas de fogo no Brasil. 2016. Disponível em: <http://www.mapadaviolencia.org.br/mapa2016_armas. php>. Acesso em: 07 set. 2017. 
MARASCHIN, J. Da leveza e da beleza: liturgia e pós-modernidade. São Paulo: ASTE, 2011.

MORAIS, R. de. O que é violência urbana. São Paulo: Abril Cultural/Brasiliense, 1985.

O PAGADOR DE PROMESSAS. Direção: Anselmo Duarte. Autor: Dias Gomes. Edição. Carlo Coimbra. Roteiro. Anselmo Duarte. Dias Gomes. Brasil, 1962. 1 DVD (118 min), color.

PAJARES ALONSO, R. L. Historia de la música en seis bloques: géneros musicales. Madrid: Visión LIbros, 2010, p. 21-23.

PAULY, E. L. Violência. In: BORTOLLETO FILHO, Fernando et al. (org.). Dicionário Brasileiro de Teologia. São Paulo: ASTE, 2008. p. 1024-1027.

RÖSSLER, D. Die Vernunft der Religion. München: Piper Verlag, 1976.

SCHLEIERMACHER, F. Die Praktische Theologie nach den Grundsäzen der Evangelischen Kirche. Berlin: O. Reimer, 1850 (1983).

VANNUCCHI, A. Liturgia e libertação. São Paulo: Loyola, 1982.

VON HOF, W. O. Lascelebraciones litúrgicas sanan. Posadas: Ediciondel Autor, 2016. VON SINNER, R; WESTPHAL, E. R. Justiça, violência e dignidade humana no Brasil. São Leopoldo, 2017. Não publicado.

WHITE, J. F. Introdução ao Culto Cristão. São Leopoldo: Sinodal, 1997.

ZALUAR, A. A pobreza explica a violência? Revista Textual, v. 1, n. 25, p. 36-42, mai. 2017.

Recebido: 23/07/2017

Received: 07/23/2017

Aprovado: 14/12/2017

Approved: 12/14/2017 